\title{
Digital Campaign to Reduce Covid-19 Pandemic Risk
}

\author{
Agus Naryoso ${ }^{1, a)}$ Arifa Rachma Febriyani ${ }^{2)}$ Rintulebda A. Kaloka ${ }^{3)}$ \\ ${ }^{1}$ Communication Department, Universitas Diponegoro, Indonesia \\ a) author correspondence: agusnaryoso@gmail.com \\ ${ }^{2}$ D4 Information and Public Relations, Vocational School of Universitas Diponegoro, Indonesia \\ ${ }^{3}$ D3 Public Relations PSDKU Universitas Diponegoro, Indonesia
}

DOI: https://doi.org/10.18196/jkm.131046

Article Info

Article history:

Received 14 Sep 2020

Revised 06 Nov 2020

Accepted 25 May

2021

\begin{abstract}
Hoaxes about COVID-19 on social media could be seen publicly and intentionally lead to inappropriate responses amid the pandemic. In this situation, the government's public relations had a role in educating the public through accurate information about COVID-19 on social media. This research aimed to describe the public's attitude towards digital campaigns to reduce the risk of COVID-19 in Central Java and the strategy behind this digital campaign. The research was designed as a descriptive study with a mixed approach method. The sampling technique used was purposive sampling. The data was collected through an online survey of 121 respondents, interviews with expert sources, and document review. Elaboration Likelihood Theory and Rhetoric Theory are used to explain the digital campaign. The results showed that most respondents (74\%) rated the Governor as prioritizing the positive appeal approach through a digital campaign. The interview results revealed that the process of composing creative content in the digital campaign was carried out through discussions between the Governor and the content creator team. During a pandemic, a creatively packaged digital campaign was a strategic step to increase public participation in implementing preventive efforts.
\end{abstract}

Keywords: Central Java Provincial Government; Covid-19; digital campaign; social media

\section{ABSTRAK}

Hoaks tentang COVID-19 di media sosial dapat menimbulkan kekhawatiran publik dan berpotensi mengarahkan pada respons yang tidak tepat di tengah pandemi. Dalam situasi tersebut, humas pemerintah berperan penting untuk mengedukasi publik melalui informasi akurat tentang COVID-19 di media sosial. Penelitian ini bermaksud untuk mendeksripsikan sikap publik terhadap kampanye digital untuk mengurangi risiko COVID-19 di Jawa Tengah dan strategi di balik perancangan kampanye digital tersebut. Jenis penelitian ini merupakan penelitian deskriptif dengan pendekatan mix method. Teknik sampling yang digunakan adalah purposive sampling. Pengumpulan data dilakukan melalui survei online kepada 121 responden, wawancara dengan narasumber ahli, dan telaah dokumen. Elaboration Likelihood Theory dan Teori Retorika digunakan untuk menjelaskan kampanye digital tersebut. Hasil penelitian menunjukkan bahwa mayoritas responden (74\%) menilai gubernur mengutamakan pendekatan positive appeal melalui kampanye digital tentang edukasi protokol kesehatan. Hasil wawancara mengungkap bahwa proses penyusunan konten kreatif dalam kampanye digital tersebut dilakukan melalui diskusi antara gubernur dan tim content creator. Pada masa pandemi, kampanye digital yang dikemas secara kreatif menjadi langkah strategis untuk meningkatkan partisipasi publik dalam menerapkan upaya preventif.

Keywords: Covid-19; kampanye digital; media sosial; Pemerintah Provinsi Jawa Tengah 


\section{INTRODUCTION}

The global COVID-19 pandemic is a concern that is being experienced by citizens of the world today. The spread is so rapid that more than 168 countries have confirmed the infection of this coronavirus. The number of positive patients infected with COVID-19 in Indonesia has also increased, although some have been declared cured. A total of 488 districts/cities in 34 provinces of Indonesia have even been declared exposed to COVID-19 (Kamil, 2020). On August 13, 2020, the official website of the Ministry of Health released several provinces with the newest cases of COVID19, namely DKI Jakarta, East Java, Central Java, North Sulawesi, and West Java (Alam, 2020).

In addition to forming a task force, the president officially declares the status of public health emergencies, referring to Law Number 6 of 2018 concerning Health Quarantine. Social distancing and physical distancing policies must be applied in a disciplined manner by all people to avoid contracting COVID-19.

To suppress the virus transmission in the community, the government's public relations play a critical role in promoting health protocol education and delivering accurate public information about COVID-19. When physical distance is being restricted, social media is seen as the right channel to educate the public to always comply with health protocols. This is in line with Evan's opinion (Syrkiewicz-S'witała et al., 2018) that social media can create an efficient way of communicating to support health promotion and education with target groups. Moreover, social media users in the country have now reached 160 million people (Haryanto, 2020). However, the main question that needs to be resolved is how effective communication strategies are so that health protocol education through social media is able to shape the expected behavior. In addition, it is also important to analyze how the public's attitude towards the educational strategy is implemented.

On the other hand, hoaxes about COVID-19 on social media are a challenge for government public relations. This can be seen from the findings of the Task Force for the Acceleration of Handling COVID-19, which managed to identify 137,829 cases of hoax about COVID-19. Of these cases, 130,680 cases have been investigated by the National Police Cyber Unit (Rikin, 2020). This condition is in line with the research results done by Collier (2018), which reveals that much information about health that is found on the internet and shared on social media is inaccurate and has the potential to mislead readers. Therefore, organizations in the public health sector need to improve their social media strategies to help internet users find accurate health information. One of the most effective new approaches to implement is to engage influencers to share valuable health content with their followers.

A similar phenomenon was revealed through the results research conducted by Geldsetzer (2020) to 3000 residents of the United States and the United Kingdom. Although most respondents have adequate general knowledge about COVID-19 - they understand how transmission of the virus occurs and its clinical symptoms - there are still misperceptions about the exemplary efforts to prevent COVID-19, including the wrong belief due to inaccurate information circulating on social media. Therefore, Geldsetzer believes the need for a campaign to disseminate accurate information about COVID-19 by the government, media, and experts in the health sector to correct the public's misperceptions.

Digital campaigns in the health sector are creative steps to persuade certain target groups. The results of the content analysis conducted by Ortiz-Martínez et al. (2019) showed that of 150 Youtube videos with the theme of "hand hygiene", 95 videos $(63.3 \%)$ contain helpful content, 29 videos (19.3\%) contain misleading content, and 26 videos $(17.3 \%)$ do not provide information. The findings of the study also showed that videos with the theme of "hand hygiene" had the most views, up to one million views. Given the benefits of health content, YouTube can serve as the right platform to promote accurate hand hygiene information on social media, of course by involving credible sources, such as doctors, centers, or organizations in the health sector.

The presence of credible sources will support the effectiveness of health education through digital campaigns. This was also explained by Aristotle through Rhetoric Theory, that there are three aspects of persuasion: ethos, pathos, and logos. The ethos aspect, in particular, focuses on the credibility of sources because, in general, the audience will be more easily persuaded by sources they think they can trust (Ofori, 2019).

Mulyana explained that the credibility of sources could be viewed from the dimensions of expertise, character or character, and dynamics (Silvia \& Paramita, 2019). The skill dimension refers to the intelligence and competence of the sources and information they have. Meanwhile, the 
character dimension refers to objectivity, motivation, or goodwill that is owned and his presence as a liked figure. Finally, the dynamic dimension refers to the source's persuasive ability, liveliness, and enthusiasm.

Apart from source credibility, Green stated that another factor that cannot be ignored in supporting a digital campaign strategy is creativity (Allagui \& Breslow, 2016). When utilizing social media, creative thinking skills need to focus on message production, not just on the technology used. According to Hamill et al., digital campaigns can achieve the expected results if they are packaged very creatively (Freeman et al., 2015). It is not impossible that digital campaigns will even get news coverage which can further increase the scope of the campaign.

Mat Zain et al. (2021) reveal the importance of digital campaign creativity to create public awareness in the health sector. Through an online survey, they targeted 178 respondents from generation $\mathrm{Z}$ to determine their perceptions of the digital campaign about the COVID-19 pandemic, which was packaged through gamification. Hawari in Mat Zain et al. (2021) calls gamification an approach that incorporates computer game elements into a non-gaming system to provide a means of enhancing user engagement and experience. Based on the results of the online survey, it is known that the majority of respondents are very interested in the gamification-based digital campaign as a public health education strategy. The majority of respondents agreed that digital health campaigns through gamification could lead to behavior change. This is in line with previous research, where the gamification approach is increasingly being applied in digital campaigns in the health sector. One of them is the Pan American Health Organization digital campaign through the video game "Pueblo pitanga: Enemigos Silenciosos" to create awareness about Dengue Hemorrhagic Fever (DHF) and malaria among children and adolescents.

Apart from the gamification approach, research (Permatasari et al., 2020) examines the Ministry of Health's campaign entitled "Prevent, Treat, Fight Diabetes" via Youtube video. Based on the Elaboration Likelihood Model theory, the results of this qualitative study revealed that credibility appeals and emotional appeals strongly influence message recipients. Central route persuasion occurs when the recipient of the message has a clinical history of Diabetes Mellitus.

Research (Pedersen et al., 2020) revealed the Human Papillomavirus (HPV) vaccination campaign strategy entitled "Stop HPV - stop cervical cancer" through Facebook and the website. Using the heart-brain communication approach, there is campaign content packaged based on facts. There is also content aimed at arousing the emotions of the target group, namely mothers who have teenage children. In addition, a community management strategy was implemented to develop a constructive dialogue among mothers about HPV vaccination. Furthermore, the effectiveness of the digital campaign is evaluated through engagement rates and click-through rates. Evaluation results show that as of January 2019, the digital campaign had reached 8,020,000 people with an average of 127 comments per post. The level of involvement from May 2017 to mid-2018 reached 6.07 percent. One year after the digital campaign was released, parents' trust in the HPV vaccination increased from 50 percent to 80 percent.

The novelty aspect of this research focuses not only on educational videos of COVID-19 as a media campaign but also examines a local official's ability to communicate using local wisdom to educate the public about the dangers of COVID-19.

This research in the field of health communication aims to describe the public's attitude towards digital campaigns to reduce the risk of COVID-19 in Central Java and the strategies behind the design of the digital campaigns. This research is essential to reveal how digital campaign strategies can increase public awareness to comply with health protocols. Given that Central Java is one of the provinces designated as the "red zone" for COVID-19 in Indonesia. This can be reviewed from the data on the official government website https://covid19.go.id/ and as reported by Dwianto (2020) that as of October 6, 2020, Central Java was in the top three provinces with the highest number of active Covid-19 cases (5,681 people) in Indonesia, after the provinces of DKI Jakarta (12,888 people) and West Java (8,980 people). However, the handling of Covid-19 in Central Java is included in the top three nationally because, based on data from the central government, the number of active Covid-19 cases in the province in the period 19-31 October 2020 continues to decline. In addition, the decline in the death rate due to Covid-19 in Central Java was also in the third highest-ranking nationally (19 cases), after West Java (80 cases) and DKI Jakarta (44 cases) (Nugroho, 2020). In addition, the figure of Ganjar Pranowo is known as one of the governors who actively interact with his citizens. The success of Central Java in conducting campaign activities to reduce pandemic cases is expected to inspire other regions in Indonesia in dealing with the Covid 19 pandemic. 


\section{METHOD}

This study uses a mixed-method approach that allows researchers to triangulate data, combining qualitative and quantitative data. This is based on the reality that each method has limitations, so the researcher tries to reduce the potential for bias in the study. The mixed-method approach is based on a pragmatic point of view, in which the researcher emphasizes efforts to provide the best understanding of the research problem being studied (Creswell, 2014).

According to Morgan (2017), mixed-method research is an intellectual and practical synthesis based on quantitative and qualitative research, so it is often referred to as the "third methodology". The research results using this approach tend to be more informative, comprehensive, balanced, and useful. Furthermore, another characteristic of the mixed method is that it coexists with a pragmatic paradigm which refers to data collection, analysis, and concluding quantitative and qualitative data. This opinion is confirmed by an explanation (Muslim, 2016) that the mixed method as a combined approach that combines quantitative and qualitative analysis is based on a pragmatic paradigm.

The purpose of using this mixed-method is to strengthen the analysis of digital campaigns to reduce the risk of the COVID-19 pandemic in Central Java from the two types of primary data obtained, namely quantitative data and qualitative data. The quantitative data was collected from an online survey on the analysis of public attitudes towards health protocol education conducted by the Governor of Central Java, Ganjar Pranowo, in a video entitled "Socialization of Handwashing Methods in Semarang Market (native title: Sosialisasi Cuci Tangan di Pasar Semarang)" which was broadcasted on Youtube. Quantitative data illustrates the respondent's assessment or attitude regarding the digital campaign video of Governor Ganjar Pranowo. The research instrument used refers to Aristotle's Rhetorical Theory, which describes several essential factors that determine the success of communicators when speaking in public, namely ethos, pathos, and logos.

Nevertheless, before that, the researcher first tested the feasibility of the research instrument online to 30 respondents to test its validity and reliability. Of the 19 question items presented, the validity test results through SPSS showed two invalid question items, so they were not used in the online follow-up survey. Meanwhile, the reliability score (Cronbach Alpha) was 0.836 .

The online survey was conducted during the period May-June 2020. A total of 121 respondents were randomly assigned to participate in the online survey. There are 17 question items submitted to respondents. Each question has a semantic differential scale with a value range of 1-5, where a score of 1 refers to the most agreeable response, while a score of 5 refers to the most agreeable response.

Furthermore, the data were processed statistically descriptive using SPSS to analyze respondents' responses to health protocol education conducted by the Governor through the video. This quantitative data was also strengthened by qualitative data in the form of in-depth interviews with a number of expert sources, namely the Central Java Province Communication and Information Agency, to outline the strategy behind the design of the COVID-19 digital campaign in Central Java. Mix Method is done by presenting qualitative data to support quantitative data. The result will be obtained an overview of campaign activities planned with a good strategy that will get a positive response or vice versa

\section{RESULT AND DISCUSSION}

The Central Java Provincial Government is aggressively conducting digital campaigns to reduce the risk of the COVID-19 pandemic. The digital campaign content includes displaying health protocol education carried out by the Governor of Central Java, Ganjar Pranowo, which was packaged in a video format and then broadcasted on Youtube.

The video entitled "Socialization of How to Wash Hands in the Semarang Market" is one of the digital campaign content featuring health protocol education by the Governor by cycling around public places. Through the video, the Governor conveyed the importance of complying with health protocols and practicing proper handwashing in front of residents.

Respondents gave responses about the health protocol education carried out by the Governor on the video. The assessment aspect refers to the creativity and relevance of the outreach for the public, the use of language, and the Governor's character as a communicator to visualize the extension video as part of the digital campaign content. The quantitative research findings are described in the subanalysis of public attitudes towards health protocol educational videos and the analysis of the Governor's character as the following outreach communicator. 


\section{Analysis of Public Attitudes towards Health Protocol Educational Videos}

The results of data processing showed that 53.71 percent of respondents rated education about health protocols during the COVID-19 pandemic by Central Java Governor Ganjar Pranowo by cycling to various public places as a very inventive step. This is because the extension model is a new approach taken by a regional leader. By gowes blusukan (literally: going into rural and sometimes slum areas with bicycle), the Governor can freely reach several public places at the same time to provide information to residents.

In addition, 48 percent of respondents considered that the Governor's extension model was very relevant to residents' social and psychological conditions. The counseling targets are shown in the video "Socialization of Handwashing in Pasar Semarang (the Semarang Market)" are traders, teachers, and the general public.

The relevance of the extension model can be viewed from the material presented. As many as 45 percent of respondents considered that the extension material was very relevant and able to answer the primary needs of the target group. In addition, 78 percent of respondents considered that the choice of language used by the Governor when conducting counseling was very easy to understand. The vocabulary used is familiar and adapts to the target of the education.

The gowes blusukan counseling videogram that is broadcasted on Youtube is considered to fulfill the logos aspect. In Rhetorical Theory, logos refers to the ability to convey messages based on solid arguments or actual data. This can be seen from the 45.83 percent of respondents who agreed that the counseling carried out by the Governor contained accurate supporting statistical data. In addition, as many as 56.30 percent of respondents considered that the visualization of the counseling videogram was also excellent. This is viewed from the accuracy of the concept, storyline, editing, and sound effects. A video about health protocol education is creatively designed to support a digital campaign to reduce the risk of COVID-19 in Central Java.

\section{Analysis of the Character of the Governor as an Extension Communicator}

The character of the communicator also determines the success of counseling. In this study, the analysis of the character of the communicator is based on several indicators. They include material mastery capacity, greeting style, persuasive style, willingness to listen, body posture, icing device persuasion method, autoplastist, phronesis, arete, eunoia, and efforts to build audience strength rise from the COVID-19 pandemic. The research findings on the character of the communicator are described as follows.

Competent communicators play an essential role in the success of persuasion efforts. A person is seen as an expert communicator when he/she mastered the material to be conveyed to the audience very well. As many as 53.34 percent of respondents considered that the capacity of mastering material about health protocols during the COVID-19 pandemic owned by the Governor of Central Java, Ganjar Pranowo, was very good. They argued that the Governor was able to convey this information in a very clear and structured manner, yet it was easy for the citizens to understand.

In addition, as many as 65 percent of respondents have a good first impression of the counseling carried out by the Governor. They considered that the style of greeting the Governor when initiating counseling was natural, spontaneous, and not different from everyday communication styles and far from being rigid. For example, in the video "Socialization of Hand Washing in Pasar Semarang", the Governor greets one of the residents who wanted to enter the market to shop but does not wash his hands first. The Governor also greeted in the local language, "Ma'am, where are you going, Ma'am. You washed your hands, yet?" which means asking for the purpose and reminding whether ones have washed their hands before entering a public place. When interacting with students who were traveling with their families, the Governor also greeted him in everyday language, "You do not go to school? You are often given homework by the teacher, huh?".

When delivering counseling on health protocols during the COVID-19 pandemic, the Governor's persuasion style was also considered very good. As many as 74 percent of respondents considered that Governor Ganjar Pranowo's persuasive style was very supportive of the success of counseling about health protocols in the midst of the COVID-19 pandemic. This can be seen from the positive appeal approach conducted by the Governor when educating residents. Governor Ganjar Pranowo is trying to build citizen awareness to adopt healthy living habits not to get infected with COVID-19. Instead of frightening citizens about the dangers of COVID-19, the Governor emphasized understanding the importance of washing hands properly, wearing masks, avoiding crowds, not making direct contact 
with other people around him, and other health protocols that are already in place. The Governor emphasizes the people to obey the protocol to maintain the health of themselves and their families.

Respondents also gave positive responses to the Governor's interaction style while the blusukan take place. As many as 41.32 percent of respondents appreciated the Governor's willingness as a regional leader to listen to the aspirations of the citizens carefully and respond well. The Governor did not interrupt the conversation when a resident expressed his opinion.

In addition, as many as 30 percent of respondents thought physical closeness or body posture governor during the counseling went very well. This body posture reflects a desire to bond and bond emotionally with the target group. Compared with indicators from other source factors, the positive response of respondents to body posture is not that great. That is considering that face-to-face counseling must be done by paying attention to a physical distance of at least one to two meters to comply with health protocols during the COVID-19 pandemic.

Respondents appreciated the Governor's ability to bind the emotions of the target group through the messages he conveyed. A total of 60 percent of respondents said that the Governor used Icing Device Persuasion Method approach during counseling. Icing Device Persuasion Method is an approach in which extension content is conveyed using words that can bind the audience's emotions, making them happy, happy, sad, or impressed. In the video "Socializing Hand Washing in the Semarang Market", the Governor did not hesitate to joke when educating residents about the importance of complying with health protocols during the COVID-19 pandemic, making them even more enthusiastic about paying attention to counseling messages. The research findings on the icing device persuasion method are consistent with the ability of pathos communicators to build emotional relationships with audiences.

In tune with the Icing Device Persuasion Method approach, respondents also considered that the interaction between the Governor and residents when counseling took place was fluid. This can be seen from 67.5 percent of respondents who assessed that the Governor used the autoplastist method when delivering education about health protocols during the COVID-19 pandemic, where this method allowed the Governor to change the way he interacted to make it more effective and efficient, so that the target audience was can be more enthusiastic about following the counseling material.

As many as 48 percent of respondents stated that the education about health protocols during the COVID-19 pandemic carried out by the Governor was very reflective phronesis. The concept of phronesis refers to intelligence which includes not only bright ideas, but also the ability of the communicator to share messages and values to the target group. Respondents argued that the Governor had creative ideas to educate residents on how to wash their hands properly. The messages conveyed are packaged in a simple, easy to understand, and familiar manner so that the messages are easily accepted by the public, including market traders.

In addition, as many as 66 percent of respondents considered that arête the Governor had when he gave information on health protocols was very good. They argue that the Governor's arete has an important role during outreach, so that the message given can be conveyed and the community implements it well. Therefore, each leader should have an honest and good image, reputation, and credibility so that the community becomes more disciplined to comply with existing regulations.

Based on the results of an online survey about the style of health protocol counseling in the midst of the COVID-19 pandemic carried out by Governor Ganjar Pranowo by means of blusukan, as many as 64 percent of respondents considered that the Governor's eunoia ability was very good. In this case, eunoia or goodwill of the communicator to his audience can be realized by means of the Governor conveying positive values to citizens through education. This is in line with the responses of 64 percent of respondents who considered that the Governor was very good in his efforts to raise hopes for citizens to rise from the COVID-19 pandemic.

Table 1. Public Attitude towards the Health Protocol Educational Video of Governor Ganjar Pranowo

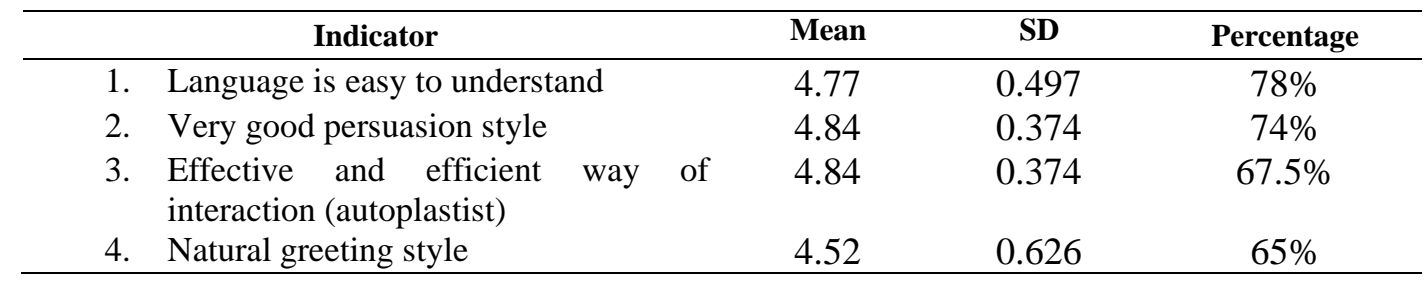




$\begin{array}{llllll}\text { 5. } & \text { Eunoia governor } & 4.77 & 0.425 & 64 \% & \\ \text { 6. } & \text { Icing Device Persuasion Method } & 4.61 & 0.667 & 60 \% & 7\end{array}$

\section{Relevance of Research Findings and Rhetoric Theory and ELT}

The Rhetorical Theory proposed by Aristotle (Ofori, 2019) explained that rhetoric is an art in which the communicator looks for the best way to persuade the audience. The character of the communicator, also known as ethos, is one aspect of rhetoric that determines the success of the persuasion process because the audience generally trusts the communicator who is seen as credible. Ethos can be viewed from several elements, namely phronesis, arete, and eunoia which are born from the speaker's attention and responsiveness to the material, context and purpose of the speech, as well as the audience.

Furthermore, the element of phronesis refers to several things, such as common sense, wisdom, skill and intelligence. Phronesis not only displays the expertise of the communicator intellectually, but also requires the sensitivity of the communicator to understand the audience situation. The wisdom possessed by the communicator will also lead him to think clearly when making decisions in difficult situations.

Furthermore, the arete element refers to the virtue or moral goodness possessed by the communicator. Communicators who have high morals do not do good merely to fulfill their own interests, but also consider the interests of others.

Lastly, the eunoia element refers to the goodwill, friendliness, and friendship that the communicator wants to forge with his audience. This element can increase persuasion power in public speaking. Apart from ethos, another aspect of the Rhetorical Theory review that determines the success of the persuasion process is emotional appeal (pathos) and the ability to present rational arguments (logos).

Meanwhile, according to Siagian (Natalia Pradipta Puteri et al., 2018), there are several sources of communicator credibility, namely:

- The honesty factor (the character of a trustworthy communicator)

- Professionalism factor (refers to the experience the communicator has)

- The dynamism factor (active communicator)

- The objectivity factor (open-mindedness, rational judgment)

The attractiveness of communicators during outreach is also supported by their ability to show nonverbal cues that are consistent with the message conveyed to the target group. This is in line with the research results conducted by Scherer, Layher, Kane, Neumann, and Campbell (Chen et al., 2014), who perform audio-visual analysis on the corpus of political speech. They found that motion energy is a visual cue that correlates with the performance of the communicator when speaking in public. Niewiadomski, Mancini, and Piana (Chen et al., 2014) also analyze the quality of expressive movements in the context of public speaking. They classified these into three categories: a) low-level features, such as speed; b) intermediate features, such as repetition, symmetry; and c) higher-order characteristics, such as gestures that contain emotional or social cues. Research from these experts reveals that public speaking performance is not only determined by the proficiency of the communicator in the language but ideally supported by relevant nonverbal cues, including gestures so that the target group is more enthusiastic and willing to follow the message conveyed.

Aristotle's opinion that the character of the communicator (ethos) is one of the determining factors for the success of persuasion is in line with the Elaboration Likelihood Theory (ELT) put forward by John Cacioppo and Richard E. Petty (Littlejohn, Stephen W., Foss, 2009). This theory explains that a persuasive message can be evaluated by the recipient in two different ways, namely through the central route and the peripheral route. Cacioppo and Petty argue that recipients of persuasive messages can process information via one of two routes, or sometimes both, and lead to a change in attitude. ELT tries to predict when and how the recipient of a message will or will not be easily persuaded.

Information processing through the central route takes place when the recipient evaluates a persuasive message based on critical thinking about the message content. The recipient of the message will be more influenced by strong arguments, and the change in attitude that occurs will lead to the formation of a strong attitude. 
Meanwhile, information processing via the peripheral route takes place when the recipient is not critical of a persuasive message and relies more on some peripheral cues, such as source credibility, message style and format, and the mood of the recipient. In this case, the recipient tends to trust credible sources. Apart from that, the recipient also tends to agree with the individual he likes.

The research findings show that the majority of respondents think that the Governor of Central Java, Ganjar Pranowo, is a credible communicator. This is in terms of intelligence (phronesis) the Governor in delivering education about health protocols during the COVID-19 pandemic. The Governor immediately practiced how to take proper handwashing steps when having dialogues with a number of mothers, then asked them to imitate. The education is also delivered in a language that is easy to understand, in accordance with the characteristics of the target group. The Governor also appealed to cleaners to ensure every visitor to wash their hands in the places that have been provided, both when entering and leaving the market.

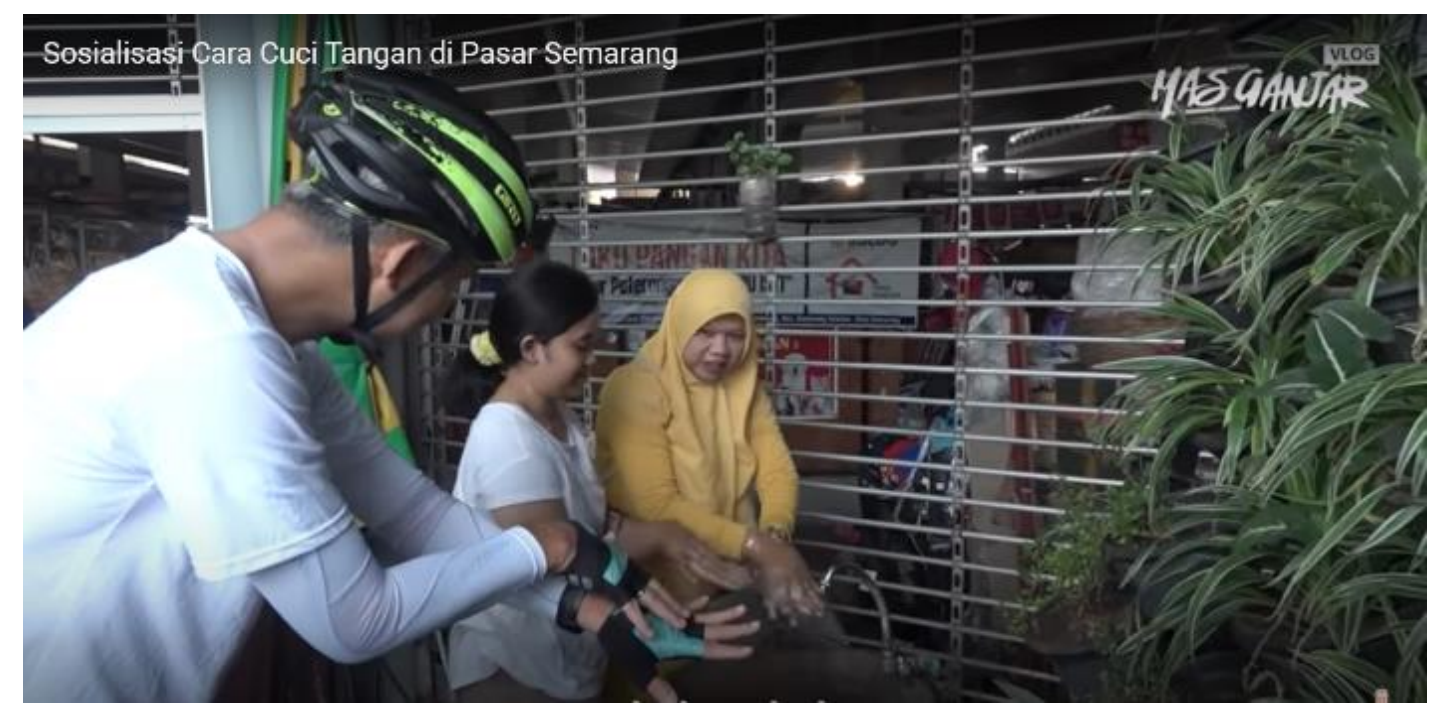

Figure 1. The Governor educates buyers who are about to enter the market on proper hand washing steps

Respondents considered the Governor to have a very good array. Not only has credibility and a positive image, but the Governor's move to convey education about health protocols during the COVID-19 pandemic to residents is also considered the right action as a preventive measure so that people do not contract the virus.

In addition, respondents also assessed that the Governor has eunoia which is reflected in his concern for citizens and seeks to raise hopes that they can rise from the COVID-19 pandemic properly if they comply with established health protocols. In another video entitled "Physical Distancing at PT Djarum Kudus", the Governor does not only teach employees to queue orderly when entering or leaving the building and maintaining a safe physical distance. The Governor also conveyed a message to employees that the COVID-19 pandemic is a difficult situation. However, this pandemic can be faced together by constantly adhering to the prevailing health protocols - not touching each other, wearing a mask, maintaining an ideal distance of 1.5 meters, and frequently washing hands using soap properly. Governor Ganjar Pranowo said that by doing this, the employees could work well. In addition, Governor Ganjar Pranowo also joked to employees whether they had received holiday allowances (THR). In the video entitled "Eligible to be Imitated, Indomaju Textindo Kudus Factory Implements Health Protocols", the Governor also invited employees to be grateful for being able to work as their previous routine, considering that many workers from other companies had to be laid off during the COVID-19 pandemic. The Governor seemed to greet the employees who were working. Indomaju Textindo Kudus Factory Implements Health Protocols" the Governor also invited employees to be grateful for being able to work as their previous routine, considering that many workers from other companies had to be laid off during the COVID-19 pandemic. The Governor seemed to greet the employees who were working. Indomaju Textindo Kudus Factory Implements Health Protocols" the Governor also invited employees to be grateful for being able to work as their previous routine, considering that many workers from other companies had to be laid off during the COVID-19 pandemic. The Governor seemed to greet the employees who were working. 
"Ma'ams, you're doing fine, right?, healthy, ma'ams?You're still all working, thank God. Most of your friends was laid off. Have you received your THR (Lebaran incentives) yet?"

In addition, the Governor is also considered to have eunoia, which is shown by paying attention to the public when carrying out education and building a friendly atmosphere. For example, when the Governor interacts with several mothers who shop at the market. The Governor appealed to mothers to queue orderly and maintain a physical distance of at least one meter. The Governor also made jokes, thereby making the interactions with the public more fluid.

Through the research findings above, it can be seen that most of the respondents paid attention to the character of the Governor as a communicator of health protocol counseling on digital campaign videos. The Governor is seen as a communicator who fulfills the ethos aspect, as stated by Aristotle in the Rhetorical Theory. This is reflected in the credibility that Governor Ganjar Pranowo has. He is considered a communicator with expertise, character, and dynamism when delivering health protocol education in public.

The credibility of the communicator who is considered to be very good shows that the majority of respondents tend to process persuasion messages (health protocol education) through the peripheral route. Another cue that supports the processing of persuasion messages on this route is the Governor's ability to arouse audience emotions (pathos). Table 1 reveals that the respondent's assessment of the Icing Device Persuasion Method indicator reached 60 percent. Icing Device Persuasion Method is an approach in which extension content is delivered using words that can bind the audience's emotional, such as making them happy, happy, sad, or impressed. In the video "Socialization of Hand Washing Methods in the Semarang Market", it appears that Governor Ganjar Pranowo does not hesitate to make jokes when delivering health protocol education in front of the public and laughing together. This method is considered to be effective in eliminating the impression of "distance" between regional leaders and citizens, so that the audience participates in counseling and processes persuasion messages in a fun, without any awkward impression. For example, the Governor reminded teachers to keep physical distance when counseling was taking place. "Come on, you can't go near. At least one meter".

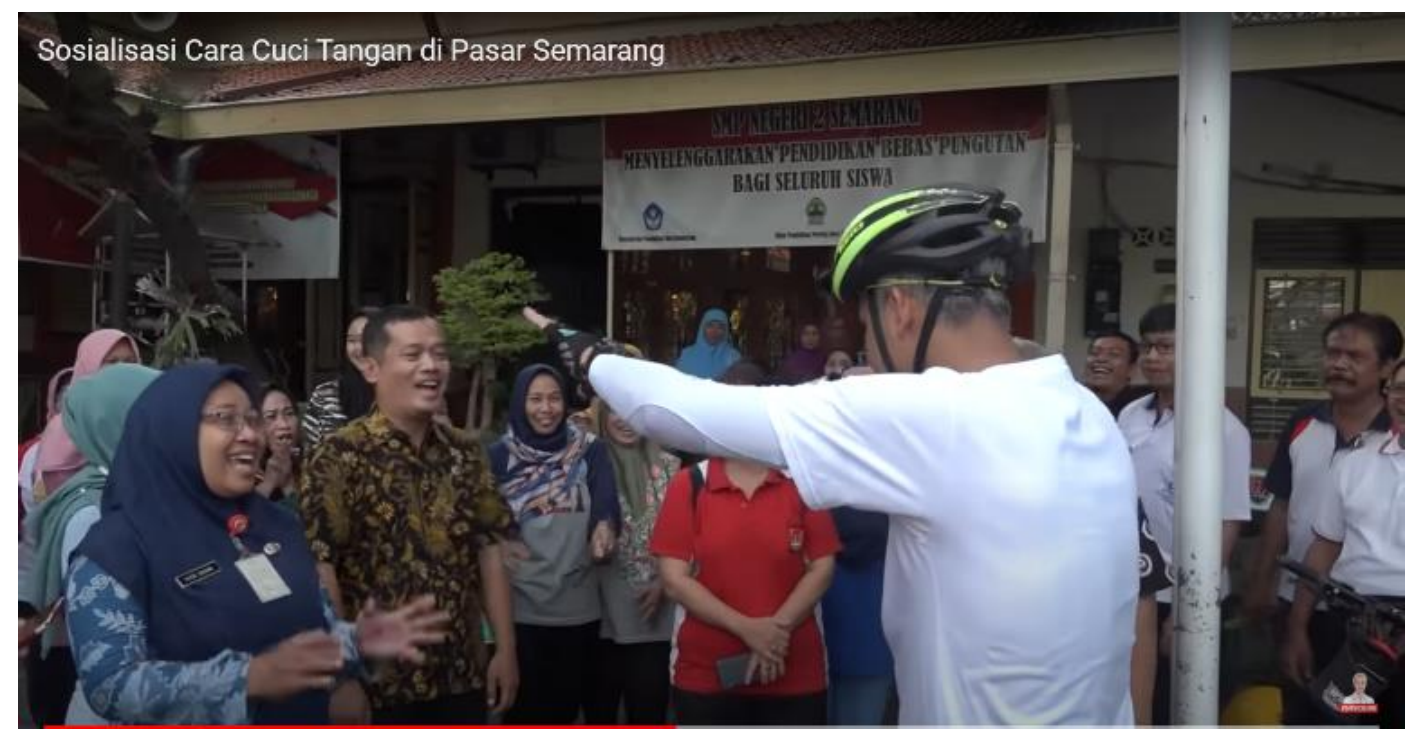

Figure 2. The Governor reminds teachers to keep physical distance by not standing close to each other

In addition to ethos and pathos, Governor Ganjar Pranowo is also considered to have logos — the ability to convey strong arguments based on facts/data, to be able to persuade the audience. This is reinforced by research findings which state that 45.83 percent of respondents agreed that the counseling carried out by the Governor contained accurate supporting statistical data. In ELT, the communicator's logos capabilities can encourage the audience to process persuasion messages from a central route. Audiences who have the motivation and critical thinking skills will look at the contents of the message based on arguments and supporting data. The processing of persuasion messages from the central route is able to form a strong attitude in the audience. 


\section{Digital Campaign Strategy to Reduce the Risk of COVID-19 in Central Java}

In today's digital era, political campaigns are often creatively designed in the format of videos uploaded on social media. (Gunarti et al., 2017) explained that political campaigns packaged in music video format present messages through visual elements that can be read or interpreted clearly and entertainingly. Gunarti argues that political campaign music videos are a form of strategy for forming perceptions in the context of social life with social and cultural values. He gave an example, during the Jakarta Pilkada in 2017, there were many campaign videos that were shown on television and social media.

A number of experts classify three types of political campaigns, namely pre-modern, modern, and post-modern. (Strömbäck, 2007) explained that each type of political communication campaign has different characteristics in terms of several aspects, including the political communication system, the dominant political communication style, the media used, and campaign coordination.

Pre-modern political campaigns were dominated by party-laden messages published through print and electronic media, such as posters, newspapers, and radio broadcasts. This type of campaign is coordinated directly by party leaders and their ranks.

Modern political campaigns tend to use television as the main medium for broadcasting campaign messages. Campaign messages are generally packaged through sound bites and image and impression management in such a way. Modern political campaigns are usually coordinated by campaign managers who come from within the party, collaborating with the media and public opinion survey experts.

Meanwhile, post-modern political campaigns make use of various media channels. This type of campaign political communication style predominantly targets specific groups (narrow-casted, targeted micro messages). This means that the campaign message is aimed at a specific audience. Post-modern campaigns are generally coordinated by special teams and assisted by political consultants.

The health protocol education carried out by the Governor is one form of post-modern political campaigning. To support his communication activities with the public, the Governor makes use of various social media channels, such as the official Twitter, Facebook, Instagram and YouTube accounts. If you look at a number of videos uploaded on the YouTube channel, it can be seen that the content is designed based on certain target groups. For example, there are several educational videos about the COVID-19 pandemic that target groups of traders, medical personnel, teachers, students and students, companies / factories, civil servants, Islamic boarding schools, and others.
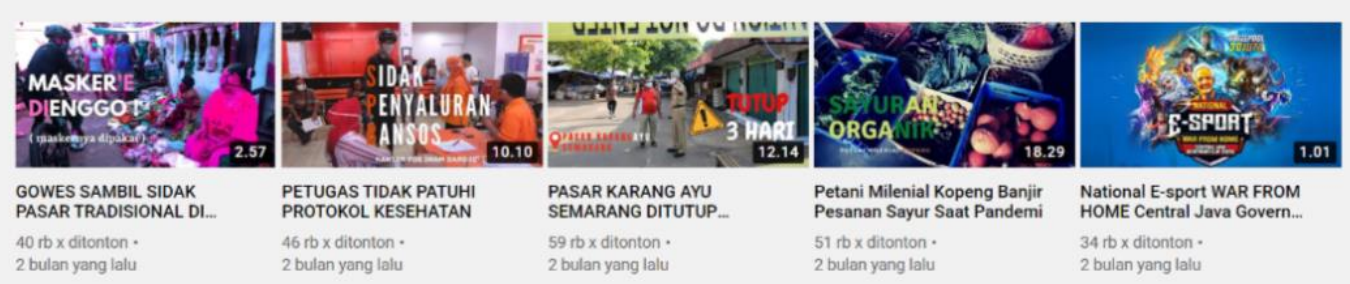

PASAR KARANG AYU SEMARANG DITUTUP 59 rib $\mathrm{x}$ ditonton. Petani Milenial Kopeng Banjir
Pesanan Sayur Saat Pandemi 40 ib x ditonton. 2 bulan yang lal

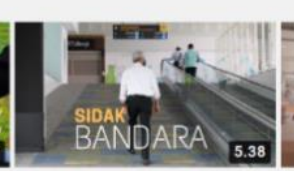
21 ib $x$ ditionton .

National E-sport WAR FROM National E-sport WAR FROM
HOME Central Java Govern. $34 \mathrm{rb} x$ ditonton -
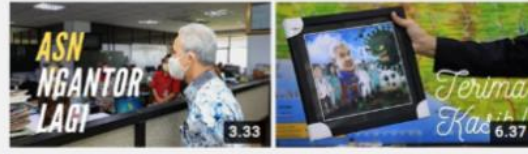

ASN PEMPROV JATENG BACK TO OFFICE

$44 \mathrm{rb} \times$ ditonton .

Hadiah dari Dokter-Dokter Hadiah dari Dokter-Dokter
RSUP Kariadi Semarang 33 rb $x$ ditonton . SIDAK! Banda
Semarang 83 rb $x$ ditonton

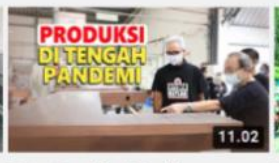
2 bulan yang lalu

Figure 3. Several educational videos on health protocols during the COVID-19 pandemic on Youtube Ganjar Pranowo

The process of designing the video was carried out through discussions between the team and the Governor, although the Governor was often the initiator of ideas or content drafter. This was revealed through an interview with the Head of the Media Relations and Public Communication Section of the Communication and Information Technology Office of Central Java Province, Enrico Adrian Ramandha. 
"Almost every day after 'isya', around 21.00 to 01.00 the discussion is limited to regular chat. The Governor has an idea that we will translate into action. On the other hand, if the team has an idea, Mr. Governor will consider it. But often the idea comes from the Gub. Even with the existence of COVID-19, the demand for content that leads to educating the public is increasing than usual. As in the past, Mr. Governor asked the team to make a narrative on the topic of providing social assistance to Central Java residents in Jakarta. Then the narrative is comprehended, agreed, and then we just take it. In addition, many posts on Mr Governor's social media have been reposted by the public. For example, the Jogo Tonggo that he Governor Gub made himself. “

Furthermore, Enrico explained that the team had a role doing research before designing digital campaign content. After the content theme is set, they will produce content every day and publish it on social media which is timed based on needs.

"Yes, the collected reports will be used as content. For example, when something goes viral, then the team will give advice to the Governor. Production of content is done one to three times a day, even seven times. However, the publication on social media is regulated. Even though it takes on weekdays, sometimes it is uploaded on weekends, depending on needs. "

Further, Enrico explained that the digital campaign to reduce COVID-19 in Central Java uses the Governor's personal social media account and is free of charge because there is no specific budget allocation for managing the digital campaign.

"By taking advantage of the free features of social media. The Central Java Governor's account was monetized so that even though there were a lot of followers and viewers, he did not take advantage even though it was his personal account."

In addition, the Governor's direct activity of posting messages on social media accounts. The team is only tasked with responding to messages from netizens delivered through direct messages.

"For direct message (DM), it is usually done by a team because there are many messages that come in. However, every article on the timeline must be from Mr. Governor himself."

Political campaigns through video are generally strengthened by a visual text modality that appears on the screen (Gunarti et al., 2017). Visual captions can appear at the beginning, middle, end of the video, or in a specific order. A visual text is a short message that carries important information, especially a campaign message. Meanwhile, the visual image modality can be arranged according to its type, namely narrative images to tell an event, descriptive images to support the information behind the event, and explanatory images to explain matters related to current facts. The two visual modalities are interrelated and can be documented. The audio modality of music is also an important visual support element. A musical element can be used as a video opening, transition, ending, or conveying the impression and nature of the political campaign itself.

Educational videos about COVID-19 conducted by the Governor include visual text, visual images, and music audio modalities. Each video contains a visual text modality in the form of Indonesian language subtitles when the Governor has a dialogue with the target group, considering that the Governor often uses the local language when educating citizens about health protocols. The visual image modality in the video is a narrative image that tells the story of the flow of education being carried out. Educational videos are also supported by back sounds and sound effects that sound upbeat, giving the impression that the educational message is fun for netizens to follow. 


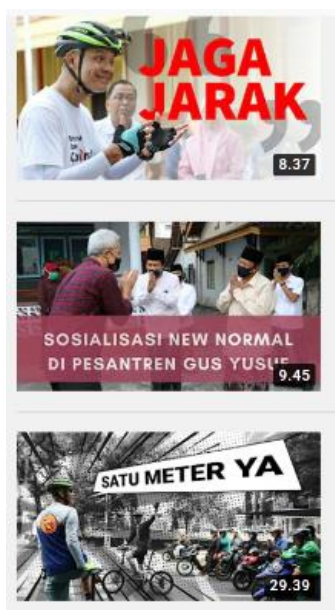

Sosialisasi Cara Cuci Tangan di Pasar Semarang

Ganjar Pranowo 051 ro x ditonton 5 bulan lalu

Di tengah wabah Covid-19, mencuci tangan merupakan cara ampuh untuk menghindarkan diri kita dari

virus corona. Akan tetapi, saya yakin tidak banyak masyarakat yang tahu dan paham cara mencuci

SOSIALISASI NEW NORMAL DI PONPES SALAF TEGALREJO

MAGELANG

Ganjar Pranowo 031 it $x$ ditonton -2 bulan lalu

Sebelum new normal diterapkan, semua orang harus sudah terbiasa dengan kondisi baru ini. ini berlaku

juga untuk para santri yang tinggal di pondok-pondok pesantren. Mereka yang sehari-harinya bel..

Social Distancing, Dipahami tapi Belum (Semuanya) Melakukan

Ganjar Pranowo $\odot 195$ rb x ditonton 5 bulan lalu.

Sepedaan hari ketiga, saya berkelling Kota Semarang lagi untuk sosialisasi social distancing kepada

Sepedaan hari ketiga, saya berkelling Kota Semarang lagi untuk sosialisasi social distancing kepada
masyarakat. Ternyata banyak yang sudah paham tapi belum melakukan social distancing. Maka ini m

Figure 4. Display of educational videos about COVID-19 Governor Ganjar Pranowo containing visual text, images, and music audio modalities

Social media has grown into a necessity for political campaigns (Vonderschmitt, 2012). Through Facebook, Twitter, and YouTube, candidates can build relationships with their constituents to encourage participation in their campaigns. When conducting persuasion in political campaigns, several things that must be considered are candidates as communicators who convey the message, the symbols and words used, and the context of the message (Newman and Perloff 2004, 30-2). Candidates or communicators must demonstrate integrity and competence to appear credible to constituents (Newman and Perloff 2004, 27). This can be supported through appearance and emotionalism. Emotionalism allows candidates to express themselves and establish relationships with the public (Lilleker 2006, 78). YouTube allows netizens to rank videos by providing likes and dislikes and showing the number of times a video has been watched. This attracts more viewers to watch the video. Not only can YouTube be used to post campaign ads, but it is also useful for posting video blogs that form a candidate's campaign trail.

Governor Ganjar Pranowo's Youtube until early September 2020 has been subscribed to by 754 thousand net citizens. The number of subscribers shows the potential to support the success of digital campaigns in order to reduce the risk of COVID-19 in Central Java. Moreover, based on the research findings, 56.30 percent of respondents considered that the visualization of the counseling videogram was also very good in terms of the accuracy of the concept, storyline, editing, and sound effects.

\section{CONCLUSION}

The digital campaign to reduce the risk of COVID-19 which is being intensively carried out by the Central Java Provincial Government needs to be carefully designed. The Governor's character who is seen as fulfilling the communicator aspects of ethos, pathos, and logos is a strength to support the digital campaign's success. Communicators who are able to persuade the audience are figures who have credibility in the eyes of the audience. In addition, communicators who are able to establish emotional closeness through the pathos aspect are able to encourage audience acceptance of the message conveyed. The natural style of communication, with the use of everyday language, proves that messages can be more easily understood by the audience. The relationship between the communicator and the audience can also be woven through the humor that is embedded in the delivery of the message so that it can generate audience enthusiasm.

However, digital campaign content needs to be supported with accurate data. The research findings revealed that some respondents $(45.83 \%)$ considered supporting data important to be displayed in the educational video. This shows that the target public (target audience) can process persuasion messages based on a central route or a peripheral route, as explained through ELT, and this persuasion message processing will influence the formation of attitudes. So that the ability of $\log$ os the ability of communicators to convey persuasive messages based on strong arguments and supporting data - is also an important factor that cannot be ignored, considering that message processing on the central route actually supports the formation of strong attitudes in the audience. 
The digital campaign video must also be designed as creatively as possible, supported by the modalities of text and visual images and audio music so that it becomes an attraction for the audience to follow the educational messages conveyed. Ideally, the publication of digital campaign content should be synergized with other social media channels so that it is more easily accessed by net citizens.

\section{REFERENCES}

Alam, S. O. (2020). 5 Provinsi di Indonesia dengan Penambahan Kasus Corona Terbanyak Per 13 Agustus. Detikhealth.Com. https://health.detik.com/berita-detikhealth/d-5131825/5-provinsidi-indonesia-dengan-penambahan-kasus-corona-terbanyak-per-13-agustus

Allagui, I., \& Breslow, H. (2016). Social media for public relations: Lessons from four effective cases. Public Relations Review, 42(1), 20-30. https://doi.org/10.1016/j.pubrev.2015.12.001

Chen, L., Feng, G., Joe, J., Leong, C. W., Kitchen, C., \& Lee, C. M. (2014). Towards automated assessment of public speaking skills using multimodal cues. ICMI 2014 - Proceedings of the 2014 International Conference on Multimodal Interaction, 3, 200-203. https://doi.org/10.1145/2663204.2663265

Collier, R. (2018). Containing health myths in the age of viral Misinformation. Cmaj, 190(19), E578. https://doi.org/10.1503/cmaj.180543

Creswell, J. W. (2014). Research Design: Quantitative, Qualitative, and Mix Methods Approaches Fourth Edition (V. Knight (ed.); 4th editio). Sage Publications.

Dwianto, A. R. (2020). Ada 63.274 Kasus Covid-19 Aktif di Indonesia, Tertinggi 10 Provinsi Ini. Health.Detik.Com. https://health.detik.com/berita-detikhealth/d-5201387/ada-63274-kasusaktif-covid-19-di-indonesia-tertinggi-di-10-provinsi-ini

Freeman, B., Potente, S., Rock, V., \& McIver, J. (2015). Social media campaigns that make a difference: What can public health learn from the corporate sector and other social change marketers? Public Health Research and Practice, 25(2), 1-8. https://doi.org/10.17061/phrp2521517

Geldsetzer, P. (2020). Knowledge and Perceptions of COVID-19 Among the General Public in the United States and the United Kingdom: A Cross-sectional Online Survey. Annals of Internal Medicine, 173(2), 157-160. https://doi.org/10.7326/M20-0912

Gunarti, W., Wardani, W., Listya, A., Winarni, R. W., \& Eview, L. I. R. (2017). Political Campaigns Music Video As A Strategy For Forming Perceptions. International Journal of Scientific \& Technology Research, 6(11), 95-98.

Haryanto, A. T. (2020). Riset: Ada 175,2 Juta Pengguna Internet di Indonesia. Inet.Detik.Com. https://inet.detik.com/cyberlife/d-4907674/riset-ada-1752-juta-pengguna-internet-diindonesia

Kamil, I. (2020). UPDATE 1 September: Kasus Suspek Covid-19 Tembus 80.675 Orang. Kompas.Com. https://nasional.kompas.com/read/2020/09/01/15282601/update-1-septemberkasus-suspek-covid-19-tembus-80675-orang

Littlejohn, Stephen W., Foss, K. A. (2009). Elaboration Likelihood Theory. In Encyclopedia of Communication Theory (pp. 330-332). Sage Publications.

Mat Zain, N. H., Johari, S. N., Abdul Aziz, S. R., Ibrahim Teo, N. H., Ishak, N. H., \& Othman, Z. (2021). Winning the Needs of the Gen Z: Gamified Health Awareness Campaign in Defeating COVID-19 Pandemic. Procedia Computer Science, 179(2020), 974-981. https://doi.org/10.1016/j.procs.2021.01.087

Morgan, D. L. (2017). Mixed methods research. The Cambridge Handbook of Sociology, 1, 153-161. https://doi.org/10.1017/9781316418376.015

Muslim. (2016). Varian-Varian Paradigma, Pendekatan, Metode, dan Jenis Penelitian dalam Ilmu Komunikasi. Wahana, $\quad 1, \quad$ No.10(10), https://journal.unpak.ac.id/index.php/wahana/article/view/654

Natalia Pradipta Puteri, Y., R. Siahaineni, R., \& Kartika Sari, D. (2018). Kredibilitas Komunikator Dalam Kasus Satinah Dan Kasus Kendeng. Komunikator, 10(2). https://doi.org/10.18196/jkm.101011 
Nugroho, W. A. (2020). Jateng Masuk Tiga Besar Terbaik Nasional Penanganan Covid-19. Antaranews.Com. https://www.antaranews.com/berita/1816740/jateng-masuk-tiga-besarterbaik-nasional-penanganan-covid-19

Ofori, D. M. (2019). Grounding Twenty-first-Century Public Relations Praxis in Aristotelian Ethos. Journal of Public Relations Research, 31(1-2), 50-69. https://doi.org/10.1080/1062726X.2019.1634074

Ortiz-Martínez, Y., Aristizábal-Agudelo, A., Arroyo-Nisperuza, Y., Niño-Mendoza, J., SotomayorHernández, A., Moreno-Uparela, S., \& Mendoza-Borja, K. (2019). Evaluation of educational content of YouTube videos focused on hand hygiene: the need for professional communication. Journal of Hospital Infection, 103(3), 356. https://doi.org/10.1016/j.jhin.2019.03.016

Pedersen, E. A., Loft, L. H., Jacobsen, S. U., Søborg, B., \& Bigaard, J. (2020). Strategic health communication on social media: Insights from a Danish social media campaign to address HPV vaccination hesitancy. Vaccine, 38(31), 4909-4915. https://doi.org/10.1016/j.vaccine.2020.05.061

Permatasari, Y., Bernadette, S., \& Kusumawardhana, I. (2020). Studi Persuasi: Analisis Terhadap Kampanye Kementerian Kesehatan "Cegah, Obati, Lawan Diabetes" Melalui YouTube. Jurnal Sosial Dan Humaniora, 4(8), 371-385. https://doi.org/10.47313/ppl.v4i8.695

Rikin, A. S. (2020). 137.829 Hoax COVID-19 Teridentifikasi Gugus Tugas. Beritasatu.Com. https://www.beritasatu.com/digital/645413-137829-hoax-covid19-teridentifikasi-gugus-tugas

Silvia, S., \& Paramita, S. (2019). Kredibilitas Komunikator Dalam Menyampaikan Pesan (Analisis Opini Generasi Milenial Pada Kepala Penerangan Kodam Jaya). Koneksi, 2(2), 569. https://doi.org/10.24912/kn.v2i2.3938

Strömbäck, J. (2007). Political Marketing and Professionalized Campaigning. Journal of Political Marketing, 6(2-3), 49-67. https://doi.org/10.1300/J199v06n02

Syrkiewicz-S'witała, M., Romaniuk, P., Strzelecka, A., Lar, K., \& Holecki, T. (2018). Prospects for the Use of Social Media Marketing Instruments in Health Promotion by Polish Marshal Offices. Frontiers in Public Health, 6(March). https://doi.org/10.3389/fpubh.2018.00065

Vonderschmitt, K. (2012). The Growing Use of Social Media in Political Campaigns: How to use Facebook, Twitter and YouTube to Create an Effective Social Media Campaign. International Journal of Social Sciences and Entrepreneurship, 2(3), 25-29. 